\title{
Pengaruh Kualitas Sumber Daya Manusia dan Kualitas Anggaran Terhadap Kinerja Keuangan Daerah Dimediasi Dengan Sistem Informasi Manajemen Daerah
}

\author{
Mahmuddin Siregar \\ Program Studi Magister Manajemen, Universitas Muhammadiyah Sumatera Utara Medan, Indonesia \\ Jl. Denai No. 217, Tegal Sari Mandala II, Medan Denai, Kota Medan, Sumatera Utara 20371 \\ Email:mahmuddin_siregar@yahoo.co.id
}

\begin{abstract}
Abstrak. Tujuan penelitian ini adalah untuk mengetahui dan menganalisis Pengaruh Kualitas SDM, Kualitas Anggaran Terhadap Kinerja Keuangan Daerah Yang Dimediasi Dengan Sistem Keuangan Daerah (SIMDA) Pada SKPD Kabupaten Deli Serdang. Metode penelitian yang dilakukan adalah penelitian eksploratif, dimana variabel diukur dengan skala likert. Metode pengumpulan data dilakukan dengan wawancara (interview), dengan daftar pertanyaan (questionnaire) dan studi dokumentasi. Populasi dalam penelitian ini adalah seluruh SKPD di Bagian Pengelola Keuangan Daerah Kabupaten Deli Serdang yang berjumlah 104 orang. Penarikan sampel dengan metode sampling jenuh atau lebih dikenal dengan istilah sensus. Dalam penelitian ini jumlah populasi relatif sedang yaitu sebanyak 104 orang. Pengolahan data menggunakan perangkat lunak SPSS versi 17, dengan analisis deskriptif dan pengujian hipotesis analisis jalur. Hasil penelitian menunjukkan bahwa variabel Kualitas SDM mempengaruhi kinerja Keuangan Daerah Kabupaten Deli Serdang, variabel kualitas Anggaran mempengaruhi kinerja Keuangan Daerah Kabupaten Deli Serdang, variabel SIMDA mempengaruhi kinerja Keuangan Daerah Kabupaten Deli Serdang dan pengaruh antara variabel kualitas SDM, kualitas Anggaran terhadap kinerja Keuangan Daerah Kabupaten Deli Serdang tidak dimediasi oleh SIMDA pada SKPD Kabupaten Deli Serdang
\end{abstract}

Kata kunci: Kualitas SDM, Kualitas Anggaran, SIMDA, Kinerja Keuangan

Abstract. The purpose of this study was to determine and analyze the Effect of HR Quality, Budget Quality on Regional Financial Performance Moderated by the Regional Management Information System (SIMDA) in regional work units (SKPD) in the Deli Serdang Regency. The research method used is exploratory research, where variables are measured on a Likert scale. The method of data collection is done by interview (interview), with a list of questions (questionnaire) and study documentation. The population in this study were all SKPDs in the Regional Financial Management Division of Deli Serdang Regency, totaling 104 people. Sampling with saturated sampling method or better known as the census. In this study the population is relatively moderate, namely 104 people. Data processing using SPSS software version 17, with descriptive analysis and hypothesis testing is path analysis. The results showed that: (1) HR quality variable influenced Financial performance; (2) variable quality of the Budget affects the performance; (3) Regional Management Information System (SIMDA) variable influences the Financial Performance (4) the influence between the variables of HR quality, Budget quality on the performance of Finance not mediated by SIMDA in Deli Serdang Regency

Keywords: HR Quality, Budget Quality, Regional Management Information System (SIMDA), Financial Performance

\section{PENDAHULUAN}

Proses perencanaan daerah perlu diimbangi oleh ketersediaan beberapa hal seperti kapasitas aparatur pemerintah, sumber dayanya baik sumber daya manusian maupun sumber dana. Berkaitan dengan hal ini, maka untuk mengukur tingkat pencapaian atas rencana yang 
ditetapkan dengan sasaran yang ingin dicapai perlu dilakukan evaluasi atas kinerja. Keberhasilan sebuah instansi pemerintahan tidak dapat diukur semata-mata hanya dari perpestif keuangannya saja. Surplus atau defisit dalam laporan keuangan tidak dapat menjadi tolak ukur keberhasilan, karena sifat dasarnya tidak mencari profit, keberhasilan sebuah instansi pemerintah juga harus diukur dari kinerjanya.

Kinerja merupakan pencapaian atas apa yang direncanakan, baik oleh pribadi maupun organisasi. Apabila pencapaian sesuai dengan yang direncanakan, maka kinerja yang dilakukan terlaksana dengan baik. Apabila pencapaian melebihi dari apa yang direncanakan dapat dikatakan kinerjanya sangat baik. Apabila pencapaian tidak sesuai dengan apa yang direncanakan atau kurang dari apa yang direncanakan, maka kinerjanya jelek.

Menurut (Halim, 2016) analisis kinerja keuangan adalah usaha mengidentifikasi ciri-ciri keuangan berdasarkan laporan keuangan yang tersedia. Dalam organisasi pemerintah untuk mengukur kinerja keuangan ada beberapa ukuran kinerja, yaitu rasio kemandirian, rasio efektivitas, rasio efisiensi, rasio pertumbuhan, dan rasio keserasian.

Kemandirian keuangan daerah menurut Undang-Undang No 32 Tahun 2004 "kemandirian keuangan daerah berarti pemerintah dapat melakukan pembiayaan dan pertanggungjawaban keuangan sendiri, melaksanakan sendiri dalam rangka asas desentralisasi". Kemandirian daerah otonom pada prinsipnya sangat tergantung dari dua hal, yakni kemampuan keuangan daerah dalam menggali sumber sumber keuangan yang ada serta ketergantungan daerah terhadap bantuan dari pemerintah pusat.

Standar Informasi Manajemen Daerah, menjelaskan bahwa laporan keuangan merupakan laporan yang terstruktur mengenai posisi keuangan dan transaksi-transaksi yang dilakukan oleh suatu entitas pelaporan. Secara spesifik, Sistem Informasi Manajemen Daerah selanjutnya disingkat SIMDA adalah suatu sistem yan mendokumentasikan,mengadministrasikan, serta mengolah data pengelolaan keuangan daerah dan data terkait lainnya menjadi informasi yang disajikan kepada masyarakat dan sebagai bahan pengambilan keputusan dalam rangka perencanaan, pelaksanaan, dan pelaporan pertanggung jawaban pemerintah daerah. informasi yang terdapat dalam laporan keuangan harus bermanfaat dan sesuai dengan kebutuhan para pengunanya, agar dalam perencanaan, pengendalian dan pengambilan keputusan dapat dilakukan dengan baik.

Menurut (Machmud, 2013), Sistem Informasi Manajemen (SIM) merupakan suatu sistem yang dapat membantu manajemen di dalam pengumpulan data, pengolahan serta analisis evaluasi data dan menyajikan ke dalam batas informasi yang bernilai dan akhirnya sampai pada pengambilan keputusan di mana informasi ini berguna untuk mendukung fungsi operasi manajemen.

Pemerintahan Kabupaten Deli Serdang merupakah salah satu kabupaten yang sudah menerapkan Sistem Informasi Manajemen Daerah, namun dalam pelaksanaannya tidak selalu mulus seperti yang dibayangkan, masih ada beberapa kendala yang ditemui oleh peneliti saat ini, diantaranya prosedur untuk melihat data secara incidentil masih terlalu lama, ini disebabkan karena kantor belum menerapkan system database relasional yang lebih efisien sehingga direct acces sulit dilakukan. Kemudian lemahnya data Management System ini terbukti belum adanya standar operasi yang baku. Namun semua permasalahan itu bukanlah menjadi hal yang menghambat kelancaran kegiatan jika didukung oleh sumber daya manusia yang handal.

Sumber Daya Manusia adalah suatu seni untuk mencapai tujuan-tujuan organisasi melalui pengaturan orang-orang lain untuk melaksanakan berbagai pekerjaan yang diperlukan, atau dengan kata lain tidak melakukan pekerjaan-pekerjaan itu sendiri. Sumber Daya Manusia juga merupakan salah satu faktor yang sangat penting dalam suatu instansi disamping faktor 
yang lain seperti modal. Oleh karena itu SDM harus dikelola dengan baik untuk meningkatkan efektivitas dan efisiensi organisasi.

Sumber Daya Manusia adalah kemampuan terpadu dari daya pikir dan daya fisik yang dimiliki individu. Pelaku dan sifatnya dilakukan oleh keturunan dan lingkungannya, sedangkan prestasi kerjanya dimotivasi oleh keinginan untuk memenuhi kepuasannya (Hasibuan, 2014).

Anggaran sebagai salah satu alat bantu manajemen memegang peranan penting karena dengan anggaran manajemen dapat merencanakan, mengatur dan mengevaluasi jalannya suatu kegiatan. Anggaran adalah rencana operasi keuangan yang mencakup estimasi pengeluaran yang diusulkan dan sumber pendapatan yang diharapkan untuk membiayainya dalam periode waktu tertentu (Julita, Jufrizen, \& Sihotang, 2014). Anggaran berperan penting dalam menentukan tingkat kebutuhan masyarakat. Pencerminan kebutuhan masyarakat dalam Anggaran Pendapatan dan Belanja Daerah ditunjukkan melalui belanja daerah yang dikeluarkan. Terbatasnya kemampuan pendanaan daerah mengharuskan pemerintah daerah untuk mengelola belanja daerah secara efisien dan efektif. Oleh sebab itu, Anggaran Pendapatan dan Belanja Daerah harus dikelola secara cermat. Menurut (Nafarin, 2012) mengemukakan bahwa anggaran adalah rencana tertulis mengenai kegiatan suatu organisasi yang dinyatakan secara kuantitatif untuk jangka waktu tertentu dan umumnya dinyatakan dalam satuan uang.

Di Kabupaten Deli Serdang, secara umum pengelolaan Anggaran sudah berkualitas dengan memenuhi prinsip-prinsip anggaran tersebut dengan baik. Dari prinsip efisien dan efektif serta nondiscretionary appropriation, dapat diketahui ketercapaian program berbagai bidang meliputi bidang pendidikan, kesehatan, sarana dan prasarana, perumahan, perhubungan, lingkungan hidup, serta bidang sosial. Prinsip ini hampir sama dengan prinsip value for money yang dikemukakan oleh (Adisasmita, 2011) yang berarti diterapkannya tiga prinsip penganggaran yakni ekonomi, efisiensi dan efektivitas. Ekonomi berkaitan dengan penggunaan anggaran minimal, efisiensi berkaitan dengan penggunaan anggaran minimal untuk melaksanakan program secara maksimal, sedangkan efektivitas berkaitan dengan tercapainya program-program pemerintah daerah. Terkait dengan kualitas Anggaran ini masih ditemui beberapa permasalahan yang muncul, di antaranya indikator capaian yang sering tidak jelas dan tidak terukur, data dasar dan asumsi yang sering kali kurang valid, serta analisis yang kurang mendalam yang mengarah pada "how to achieve" suatu target.

\section{LANDASAN TEORI}

\section{Kinerja Keuangan Daerah.}

Kinerja merupakan suatu hasil kerja yang dihasilkan oleh seorang pegawai diartikan untuk mencapai tujuan yang diharapkan. Selain itu kinerja dapat diartikan sebagai Kinerja merupakan terjemahan dari performance yang berarti Hasil kerja seorang pekerja, sebuah proses manajemen atau suatu organisasi secara keseluruhan, dimana hasil kerja tersebut harus dapat ditunjukkan buktinya secara konkrit dan dapat diukur (dibandingkan dengan standar yang telah ditentukan). Notoatmodjo, (2015) mengemukakan bahwa kinerja adalah apa yang dapat dikerjakan oleh seseorang sesuai dengan tugas dan fungsinya. Kinerja merupakan kinerja karyawan merupakan hasil kerja dari karyawan baik dari segi kualitas maupun kuantitas dalam melakukan dan menyelesaikan tugas yang dibebankan kepada karyawan tersebut oleh atasan atau pimpinannya berdasarkan perannya di dalam perusahaan. Kinerja karyawan merupakan faktor penting yang harus diperhatikan oleh perusahaan (Arianty, Bahagia, Lubis, \& Siswadi, 2016). Kinerja karyawan akan sangat mempengaruhi produktivitas perusahaan secara keseluruhan. Produktivitas perusahaan akan rendah apabila kinerja karyawan dalam 
perusahaan tersebut rendah, dan sebaliknya perusahaan akan menjadi produktif dan semakin berkembang jika kinerja karyawannya tinggi. Kinerja karyawan akan sangat mempengaruhi hasil kerjanya (Jufrizen, 2016).

Reformasi keuangan daerah dapat dikatakan merupakan peluang terbesar sekaligus ancaman yang diperoleh pemerintah daerah dan DPRD, untuk menunjukkan kemampuan menggali dan mengelola anggaran daerah tanpa terlalu banyak campur tangan dari pemerintah pusat.

\section{Sistem Informasi Manajemen Daerah (SIMDA).}

Teknologi informasi adalah suatu teknologi yang digunakan untuk mengolah data, termasuk memproses, mendapatkan, menyusun, menyimpan, dalam berbagai cara untuk menghasilkan informasi yang berkualitas, yaitu informasi yang relevan, akurat dan tepat waktu, yang digunakan untuk keperluan pribadi, bisnis, dan pemerintahan dan merupakan informasi yang strategis untuk pengambilan keputusan.

Mulyono, (2010) menyatakan bahwa sistem adalah suatu kerangka kerja terpadu yang mempunyai satu sasaran atau lebih, selain itu sistem adalah sekelompok elemen-elemen yang terintegrasi dengan maksud yang sama untuk mencapai suatu tujuan. Kemudian data yang telah diolah menjadi bentuk yang berarti bagi penerimanya dan bermanfaat dalam mengambil keputusan saat ini atau mendatang.

\section{Kualitas Sumber Daya Manusia (SDM).}

Sumber daya manusia memainkan peran penting baik dalam skala mikro (organisasi) maupun dalam skala makro (negara). Pada setiap organisasi, besar atau kecil, bertaraf internasional, regional ataupun domestik, kunci keberhasilan utama bagi organisasi tersebut terletak pada kualitas sumber daya manusia yang mengendalikan dan menjalankannya. Sumber daya manusia merupakan satu-satunya sumber daya yang memiliki akal perasaan, keinginan, keterampilan, pengetahuan, dorongan, daya dan karya (rasio, rasa dan karsa). Tanpa adanya unsur manusia dalam perusahaan, tidak mungkin perusahaan tersebut dapat bergerak dan berjalan menuju yang diinginkan. SDM perlu dikelola secara baik dan professional agar dapat tercipta keseimbangan antara kebutuhan SDM dengan tuntutan serta kemajuan bisnis perusahaan. Werther \& Davis, (1996), menyatakan bahwa sumber daya manusia adalah pegawai yang siap, mampu dan siaga dalam mencapai tujuan-tujuan organisasi. Sebagaimana dikemukakan bahwa dimensi pokok sisi sumber daya adalah kontribusinya terhadap organisasi, sedangkan dimensi pokok manusia adalah perlakuan kontribusi terhadapnya yang pada gilirannya akan menentukan kualitas dan kapabilitas hidupnya.

\section{METODE PENELITIAN}

Metode penelitian yang digunakan pada penelitian ini adalah deskriptif kuantitatif, dimana variabel diukur dengan skala likert. Jumlah sampel sebanyak 104 orang dipilih dengan Metode Stratified Proportional RandomSampling dari 140 orang seluruh pengelola keuangan pada Satuan Kerja Perangkat Daerah (SKPD) dan Staff di kabupaten Deli Serdang. Pengumpulan data dilakukan dengan kuesioner, observasi, dan wawancara. Instrumen penelitian menggunakan skala Likert yang telah dimodifikasi dengan skala 1-5. Uji validitas instrumen dilakukan dengan menghitung nilai korelasi product moment dari tiap-tiap butir pernyataan dan didapat hasil bahwa semua butir pertanyaan memiliki nilai. Uji reliabilitas dilakukan dengan menghitung nilai koefisien alpha dari semua variabel dan diperoleh hasil semua variabel menunjukkan nilai di atas 0,60 yang berarti semua variabel adalah reliabel. 
Pengolahan data menggunakan perangkat lunak SPSS versi 24, dengan pengujian instrument, pengujian asumsi klasik, dan teknik analisi data menggunakan analisis regresi linier berganda.

\section{HASIL DAN PEMBAHASAN PENELITIAN \\ Uji Asumsi Klasik \\ Uji Normalitas}

Uji normalitas data bertujuan untuk menguji apakah dalam model regresi antara variabel bebas dan variabel terikat mempunyai distribusi normal atau tidak dengan menggunakan uji Kolmogorov- Smirnov test. Uji dilakukan untuk mengetahui distribusi data normal atau tidak.

a. Jika nilai Asymp sig $>0.5$ Maka data Berdistribusi normal

b. Jika nilai Asymp sig < 0,5 Maka data tidak normal

Tabel 1. One-Sample Kolmogorov-Smirnov Test

\begin{tabular}{llr}
\hline & & Unstandardized Residual \\
\hline $\mathrm{N}$ & & 104 \\
\hline Normal Parametersa & Mean & 0.0000000 \\
\cline { 2 - 3 } & Std. Deviation & 2.37326819 \\
\hline Most Extreme & Absolute & 0.051 \\
\cline { 2 - 3 } Differences & Positive & 0.051 \\
\cline { 2 - 3 } & Negative & -0.042 \\
\hline Kolmogorov-Smirnov Z & 0.515 \\
\hline Asymp. Sig. (2-tailed) & 0.953 \\
\hline a. Test distribution is Normal.
\end{tabular}

Pada Tabe 1 terlihat bahwa nilai Asymp. Sig. (2-tailed) adalah 0,953 dan diatas nilai signifikansi $(0,5)$ hal ini berarti variabel residual data berdistribusi normal.

\section{Uji Heteroskedastisitas}

Metode ini digunakan untuk menguji apakah dalam sebuah model regresi terjadi kesamaan varians dari residual pada satu pengamatan ke pengamatan lainnya (Juliandi, Irfan, \& Manurung, 2014).

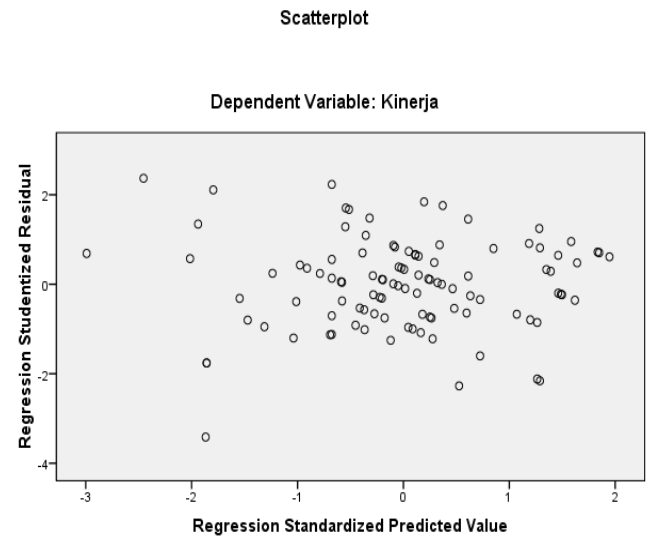

\section{Gambar 1. Scatterplot Uji Heteroskedastisitas Model Pertama}

Pada Gambar 1 grafik scatterplot terlihat titik-titik menyebar secara acak dan tidak membentuk sebuah pola tertentu yang jelas, serta tersebar baik di atas maupun dibawah angka 0 pada sumbu Y. Hal ini berarti tidak terjadi heteroskedastisitas pada model regresi, sehingga 
model regresi layak dipakai untuk memprediksi kinerja keuangan berdasarkan masukan variabel kualitas SDM, kualitas Anggaran dan SIMDA.

\section{Analisis Regresi Berganda}

Model regresi liniear berganda dilakukan untuk mengetahui seberapa besar pengaruh variabel bebas (kualitas SDM, kualitas Anggaran dan SIMDA sebagai variabel moderating terhadap variabel terikat kinerja. Analisis dilakukan dengan bantuan program SPSS Statistics 17.0 for windows.

Tabel 2. Analisis Regresi Berganda Model Pertama

\begin{tabular}{|c|c|c|c|c|c|}
\hline \multirow[b]{2}{*}{ Model } & \multicolumn{2}{|c|}{ Unstandardized } & \multirow{2}{*}{$\frac{\text { Standardized }}{\text { Beta }}$} & \multirow[b]{2}{*}{$\mathrm{t}$} & \multirow[b]{2}{*}{ Sig. } \\
\hline & B & Std. Error & & & \\
\hline (Constant) & 9.660 & 2.758 & & 3.502 & 0.001 \\
\hline Kualitas SDM & 0.217 & 0.102 & 0.195 & 2.121 & 0.003 \\
\hline Kualitas & 0.251 & 0.077 & 0.347 & 3.266 & 0.001 \\
\hline SIMDA & 0.309 & 0.109 & 0.141 & 2.831 & 0.002 \\
\hline
\end{tabular}

a. Dependent Variable: Kinerja ini yaitu:

Berdasarkan Tabel 2 diperoleh model persamaan regresi linear berganda dalam penelitian

$$
\mathrm{Y}=9.660+0,217 \mathrm{X}_{1}+0,251 \mathrm{X}_{2}+0,309 \mathrm{X}_{3}+\mathrm{e}
$$

Berdasarkan persamaan tersebut dapat di uraikan sebagai berikut:

a. Konstanta bernilai 9,660 menunjukkan bahwa jika tidak ada pengaruh dari variabel bebas $\left(\mathrm{X}_{1}, \mathrm{X}_{2}, \mathrm{X}_{3}\right)$ maka kinerja (Y) akan bernilai 9.660.

b. Nilai koefisien yang bertanda positif menunjukkan bahwa semakin tinggi nilai variabel bebas $\left(\mathrm{X}_{1}, \mathrm{X}_{2}, \mathrm{X}_{3}\right)$ maka nilai kinerja $(\mathrm{Y})$ akan semakin tinggi.

c. Nilai koefisien regresi yang bertanda negatif menunjukan bahwa semakin tinggi nilai variabel bebas $\left(\mathrm{X}_{1}, \mathrm{X}_{2}, \mathrm{X}_{3}\right)$ maka nilai kinerja $(\mathrm{Y})$ semakin rendah.

d. Koefisien $X_{1}\left(\beta_{1}\right)=0,217$, ini menunjukkan setiap terjadi peningkatan variabel kualitas SDM sebesar satu satuan maka akan meningkatkan kinerja keuangan sebesar 0,217.

e. Koefisien $X_{2}\left(\beta_{2}\right)=0,251$, ini menunjukkan setiap terjadi peningkatan variabel kualitas Anggaran sebesar satu satuan maka akan meningkatkan kinerja keuangan sebesar 0,251.

f. Koefisien $X_{3}\left(\beta_{3}\right)=0,309$, ini menunjukkan setiap terjadi peningkatan variabel SIMDA sebesar satu satuan maka akan meningkatkan kinerja keuangan sebesar 0,309.

\section{Koefisien Determinasi $\left(\mathbf{R}^{2}\right)$}

Nilai koefesien determinasi dipergunakan untuk mengetahui kemampuan variabel bebas dalam menjelaskan variasi dari variabel terikat.

Tabel 3. Hasil Pengujian Koefisien Determinasi Model Pertama

\begin{tabular}{lcccr}
\hline Model & R & R Square & $\begin{array}{c}\text { Adjusted R } \\
\text { Square }\end{array}$ & $\begin{array}{c}\text { Std. Error of the } \\
\text { Estimate }\end{array}$ \\
\hline 1 & $0.687^{\text {a }}$ & 0.472 & 0.456 & 2.409 \\
\hline a. Predictors: (Constant), SIMDA, Kualitas SDM, Kualitas Anggaran \\
\hline \multicolumn{4}{l}{ b. Dependent Variable: Kinerja } \\
\hline
\end{tabular}

Berdasarkan Tabel 3 dapat diinterpretasikan bahwa angka R sebesar 0,456 menunjukkan bahwa tingkat korelasi atau hubungan antara kualitas SDM, kualitas Anggaran, SIMDA dan 
kinerja keuangan memiliki hubungan yang cukup erat. Hasil penelitian ini menunjukkan bahwa nilai adjusted $\left(\mathrm{R}^{2}\right)$ adalah 0,456 atau 45,6\%. Artinya 45,6\% kinerja keuangan dapat dijelaskan oleh variabel kualitas SDM, kualitas Anggaran dan SIMDA. Sedangkan sisanya sebesar 54,4\% dijelaskan oleh sebab-sebab yang lain yang tidak diteliti dalam penelitian ini contohnya semangat kerja, disiplin kerja dan lain-lain.

Tabel 4. Hasil Perhitungan Analysis Jalur (Path Analysis)

\begin{tabular}{ccc}
\hline & Pengaruh Langsung & $\begin{array}{c}\text { Pengaruh Tidak } \\
\text { Langsung }\end{array}$ \\
$\mathrm{X} 1-\mathrm{Y} 1$ & 0,195 & \\
$\mathrm{X} 2-\mathrm{Y} 1$ & 0,347 & \\
$\mathrm{Y} 1-\mathrm{Y} 2$ & 0,141 & \\
$\mathrm{X} 1-\mathrm{Y} 2$ & 0,355 & \\
$\mathrm{X} 2-\mathrm{Y} 2$ & 0,651 & $(0,195 \times 0,141)=0,027495$ \\
$\mathrm{X} 1-\mathrm{Y} 1-\mathrm{Y} 2$ & & $(0,347 \times 0,141)=0,048927$ \\
$\mathrm{X} 2-\mathrm{Y} 1-\mathrm{Y} 2$ & & \\
\hline
\end{tabular}

Berdasarkan tabel diatas dan gambar diatas dapat diketahui bahwa pengaruh variabel kualitas SDM (X1) terhadap (Y2) secara langsung sebesar 0,355 sedangkan pengaruh tidak langsungnya sebesar 0,027495; dari hasil tersebut dapat dilihat bahwa pengaruh kualitas SDM terhadap kinerja keuangan lebih besar pengaruh langsungnya (tidak melalui variabel intervening SIMDA). Hal tersebut menyartakan bahwa dengan Kualitas SDM yang baik akan membuat kinerja keuangan menjadi lebih baik secara pengaruh langsung.

Berdasarkan tabel diatas dan gambar diatas dapat diketahui bahwa pengaruh variabel kualitas Anggaran (X2) terhadap (Y2) secara langsung sebesar 0,651 sedangkan pengaruh tidak langsungnya sebesar 0,048927; dari hasil tersebut dapat dilihat bahwa pengaruh kualitas Anggaran terhadap kinerja keuangan lebih besar pengaruh langsungnya (tidak melalui variabel intervening SIMDA). Hal tersebut menyatakan bahwa dengan kualitas Anggaran yang baik akan membuat kinerja keuangan menjadi lebih baik secara pengaruh langsung.

\section{Pembahasan}

\section{Pengaruh Kualitas Sumber Daya Manusia terhadap Kinerja Keuangan Daerah}

Berdasarkan hasil penelitian diperoleh bahwa kualitas sumber daya manusia berpengaruh positif signifikan terhadap kinerja keuangan daerah. Hal ini disebabkan pentingnya kualitas sumber daya manusia pada Satuan Kerja Perangkat Daerah (SKPD) Kabupaten Deli Serdang baik berupa latar belakang pendidikan, mengikuti pendidikan/pelatihan dan pengalaman merupakan faktor penting dalam meningkatkan kinerja keuangan daerah secara ekonomis, efisien, dan efektif. Faktor terpenting dan paling menentukan adalah pengalaman yang ditunjukkan dengan loading faktor tertinggi. Hal ini menunjukan bahwa dengan adanya pengalaman yang dimiliki oleh pengelola keuangan Satuan Kerja Perangkat daerah (SKPD) maka akan mengurangi tingkat kesalahan dalam menyelesaikan pekerjaan sehingga akan meningkatkan kinerja keuangan yang efisien dengan tujuan untuk mencapai kesejahteraan masyarakat. Kondisi ini memberikan gambaran bahwa kualitas sumber daya manusia mempunyai peran penting dalam peningkatan kinerja keuangan daerah pada SKPD yang ada di Kabupaten Deli Serdang. Warisno, (2009) yang mengatakan bahwa Sumber daya manusia adalah salah satu elemen organisasi yang sangat penting, oleh karena itu harus dipastikan bahwa pengelolaan sumber daya manusia dilakukan sebaik mungkin agar mampu memberikan kontribusi secara optimal dalam upaya pencapaian tujuan organisasi. Hasil penelitian ini mendukung penelitian dari (Sung, Sun Young, Choi, 2011); (Gomes, Alfinito, \& Albuquerque, 
2013) dan (Riawan, 2016) menunjukkan bahwa kualitas sumber daya manusia berpengaruh positif signifikan terhadap kinerja keuangan.

\section{Pengaruh Kualitas Anggaran Terhadap Kinerja Keuangan Daerah}

Berdasarkan hasil penelitian diperoleh bahwa kualitas anggaran berpengaruh positif signifikan terhadap kinerja keuangan daerah. Hal ini disebabkan pentingnya kualitas anggaran pada Satuan Kerja Perangkat Daerah (SKPD) Kabupaten Deli Serdang baik berupa perencanaan anggaran, kejelasan sasaran anggaran, dan evaluasi anggaran merupakan faktor penting dalam meningkatkan kinerja keuangan daerah secara ekonomis, efisien, dan efektif. Faktor terpenting dan paling menentukan adalah evaluasi anggaran yang ditunjukkan dengan loading faktor tertinggi. Hal ini menunjukan bahwa evaluasi anggaran yang dilakukan secara optimal akan menghindari terjadi penyimpangan dan kecurangan dalam pengeloaan keuangan daerah sehingga akan meningkatkan kinerja keuangan yang efisien dengan tujuan untuk mencapai kesejahteraan masyarakat. Hasil penelitian ini mengindikasikan bahwa tinggi dan rendahnya kualitas anggaran akan mempengaruhi tinggi dan rendahnya kinerja keuangan, dengan kata lain apabila kualitas anggaran tinggi maka kinerja keuangan akan meningkat sebaliknya apabila kualitas anggaran rendah maka kinerja keuangan juga rendah.. Hasil penelitian ini mendukung penelitian dari (Qi, 2010) dan (Silva \& Jayamaha, 2012) dan (Riawan, 2016) menunjukkan bahwa kualitas anggaran berpengaruh positif signifikan terhadap kinerja keuangan. Hal ini menunjukan bahwa semakin tinggi kualitas anggaran (perencanaan anggaran, kejelasan sasaran anggaran dan evaluasi anggaran) maka akan tercapai kinerja keuangan yang baik. Dengan demikian, yang harus dilakukan oleh setiap Satuan Kerja Perangkat Daerah adalah memaksimalkan kualitas anggaran melalui perencanaan anggaran yang optimal di setiap SKPD, menggambarkan sasaran yang jelas agar dimengerti oleh yang bertanggung jawab atas pencapaian sasaran anggaran tersebut, serta melakukan evaluasi anggaran agar tidak terjadi penyimpangan sehingga akan menghasilkan kinerja keuangan yang baik.

\section{Pengaruh Sistem Informasi Manajemen Daerah (SIMDA) Dalam Memediasi Pengaruh Kualitas Sumber Daya Manusia Terhadap Kinerja Keuangan Daerah}

Berdasarkan hasil penelitian diperoleh bahwa pengaruh kualitas sumber daya manusia terhadap kinerja keuangan daerah ketika di mediasi oleh Sistem Informasi Manajemen Daerah (SIMDA) tidak lebih besar daripada pengaruh langsung. Hal ini berarti bahwa Sistem Informasi Manajemen Daerah (SIMDA) bukan memediasi pengaruh pengaruh kualitas sumber daya manusia terhadap kinerja keuangan daerah. Hal ini disebabkan pentingnya Sistem Informasi manajemen Daerah (SIMDA) pada Satuan Kerja Perangkat Daerah (SKPD) Kabupaten Deli Serdang dalam pengelolaan keuangan dimana Sistem Informasi Manajemen Daerah (SIMDA) dapat menghasilkan informasi yang akurat, membantu keberhasilan pengelolaan keuangan, serta memiliki kemanfaatan yang baik dalam memproses data sehingga dapat menciptakan tata kelola keuangan secara ekonomis, efisien dan efektif bila dibandingkan dengan cara manual. Hasil penelitian ini mengindikasikan bahwa semakin baik pemanfaatan SIMDA maka memperkuat pengaruh kualitas sumber daya manusia dalam meningkatkan kinerja keuangan daerah. Hasil penelitian ini mendukung penelitian dari (Budiman \& Arza, 2013) yang menyatakan bahwa dengan menggunakan aplikasi SIMDA secara benar dapat membantu peningkatan kinerja dan kualitas kerja dari pegawai SKPD kearah lebih baik serta mempercepat pekerjaan sehingga pekerjaan lebih efektif. Dengan demikian, yang harus dilakukan oleh setiap Satuan Kerja Perangkat Daerah adalah memaksimalkan pemanfaatan Sistem Informasi 
Manajemen Daerah (SIMDA) agar bisa membantu pengelola keuangan dalam mengelola keuangan setiap SKPD sehingga tercapai kinerja keuangan yang baik.

\section{Pengaruh Sistem Informasi Manajemen Daerah (SIMDA) Dalam Memediasi Pengaruh Kualitas Anggaran Terhadap Kinerja Keuangan Daerah}

Berdasarkan hasil penelitian diperoleh bahwa pengaruh kualitas anggaran terhadap kinerja keuangan tidak dimediasi oleh Sistem Informasi Manajemen Daerah (SIMDA). Hal ini berarti bahwa Sistem Informasi Manajemen Daerah (SIMDA) bukanlah memediasi pengaruh kualitas anggaran terhadap kinerja keuangan daerah. Hal ini disebabkan pentingnya Sistem Informasi manajemen Daerah (SIMDA) pada Satuan Kerja Perangkat Daerah (SKPD) Kabupaten Deli Serdang dalam penganggaran dimana Sistem Informasi Manajemen Daerah (SIMDA) dapat menghasilkan informasi yang akurat, membantu keberhasilan pengelolaan keuangan, serta memiliki kemanfaatan yang baik dalam memproses data sehingga dapat menciptakan tata kelola keuangan secara ekonomis, efisien dan efektif bila dibandingkan dengan cara manual. Kondisi ini memberikan gambaran bahwa Sistem Informasi Manajemen Daerah (SIMDA) mempunyai peran penting dalam memperkuat pengaruh kualitas anggaran dalam upaya peningkatan kinerja keuangan daerah di Kabupaten Deli Serdang. Hasil penelitian ini mengindikasikan bahwa semakin baik pemanfaatan SIMDA maka memperkuat kualitas anggaran dalam meningkatkan kinerja keuangan daerah. Hal ini sesuai dengan penelitian yang dilakukan oleh (Sudaryati, 2013) mengungkapkan bahwa Sistem Informasi Manajemen Daerah (SIMDA) merupakan sarana untuk membantu kegiatan pengelolaan keuangan daerah yang mencakup kegiatan penganggaran, penatausahaan keuangan. Hasil penelitian ini mendukung penelitian dari (Sudaryati, 2013) bahwa penganggaran berpengaruh positif signifikan terhadap kinerja melalui sistem informasi keuangan daerah.

\section{KESIMPULAN}

Berdasarkan hasil analisis yang telah dibahas pada bab terdahulu, maka dapat ditarik kesimpulan bahwa secara variabel Kualitas SDM mempengaruhi kinerja Keuangan Daerah Kabupaten Deli Serdang, variabel kualitas Anggaran mempengaruhi kinerja Keuangan Daerah Kabupaten Deli Serdang, variabel SIMDA mempengaruhi kinerja Keuangan Daerah Kabupaten Deli Serdang dan pengaruh antara variabel kualitas SDM, kualitas Anggaran terhadap kinerja Keuangan Daerah Kabupaten Deli Serdang tidak dimediasi oleh SIMDA pada SKPD Kabupaten Deli Serdang. Berdasarkan hasil penelitian penulis memberikan beberapa saran, yaitu untuk setiap Satuan Kerja Perangkat Daerah (SKPD) Kabupaten Deli Serdang agar dapat meningkatkan kualitas sumber daya manusia, dengan faktor terpenting dan paling menentukan adalah hasil yang dicapai. Dengan adanya pengalaman pengelola keuangan Satuan Kerja Perangkat daerah (SKPD) yang semakin baik maka akan mengurangi tingkat kesalahan dalam menyelesaikan pekerjaan sehingga akan meningkatkan kinerja keuangan yang efisien. Pimpinan Bagian Pengelola Keuangan Pemerintah Kabupaten Deli Serdang meningkatkan kinerja keuangan daerah dengan meningkatkan kualitas anggaran, dengan faktor terpenting dan paling menentukan adalah evaluasi anggaran.

\section{DAFTAR PUSTAKA}

Adisasmita, R. (2011). Pengelolaan Pendapatan dan Anggaran Daerah. Yogyakarta: Graha Ilmu.

Arianty, N., Bahagia, R., Lubis, A. A., \& Siswadi, Y. (2016). Manajemen Sumber Daya Manusia. Medan: Perdana Publishing.

Budiman, F., \& Arza, F. I. (2013). Pendekatan Technology Acceptance Model Dalam 
Kesuksesan Implementasi Sistem Informasi Manajamen Daerah. JUrnal Wahana Riset Akuntansi, 1(1), 87-110.

Gomes, R. C., Alfinito, S., \& Albuquerque, P. H. M. (2013). Analyzing local government financial performance: evidence from Brazilian municipalities 2005-2008. Revista de $\begin{array}{llll}\text { Administração } & \text { Contemporânea, } & \text { 704-719) }\end{array}$ https://doi.org/10.1590/s1415-65552013000600005

Halim, A. (2016). Manajemen Keuangan Sektor Publik. Jakarta: Salemba Empat.

Hasibuan, M. S. . (2014). Manajemen Sumber Daya Manusia. Jakarta: Bumi Aksara.

Jufrizen, J. (2016). Efek Mediasi Kepuasan Kerja Pada Pengaruh Kompensasi Terhadap Kinerja Karyawan. Jurnal Ilmiah Manajemen Dan Bisnis, 17(1).

Juliandi, A., Irfan, \& Manurung, S. (2014). Metode Penelitian Bisnis. Medan: UMSU Press.

Julita, J., Jufrizen, J., \& Sihotang, I. M. (2014). Penganggaran Perusahaan Pedoman, Pengkoordinasian, dan Pengawasan Kerja. Bandung: Citapustaka Media.

Machmud, R. (2013). Hubungan Sistem Informasi Manajemen Dan Pelayanan Dengan Kinerja Pegawai Pada Rutan Makassar. Jurnal Capacity STIE AMKOP Makassar, 9(1), 78-85.

Mulyono, A. (2010). Perancangan Model Penerapan Sistem Manajemen Kinerja. Yogyakarta: Ar-Ruzz Media.

Nafarin, M. (2012). Penganggaran Perusahaan. Jakarta: Salemba Empat.

Notoatmodjo, S. (2015). Pengembangan Sumber Daya Manusia. Jakarta: Rineka Cipta.

Qi, Y. (2010). The Impact of the Budgeting Process on Performance in Small and Medium-Sized Firms in China. Dissertation University of Twente.

Riawan, R. (2016). Pengaruh Kualitas Sumber Daya Manusia dan Kualitas Anggaran Terhadap Kinerja Keuangan Daerah Yang Dimoderasi Dengan SIMDA Pada SKPD Kabupaten Buton Utara. Jurnal Ekonomi \& Studi Pembangunan, 8(1), 50-60.

Silva, L. M. ., \& Jayamaha, A. (2012). Budgetary Process and Organizational Performance of Apparel Industry in Sri Lanka. Journal of Emerging Trends in Economics and Management Sciences, 3(4), 354-360.

Sudaryati, D. (2013). Pengaruh Penganggaran Terhadap Kinerja Aparat Pemda Melalui Sistem Informasi Keuangan Daerah (Studi Kasus: Pemda Kab. Kudus). Jurnal Ekonomi Dan Bisnis, 12(1), 11-24.

Sung, Sun Young, Choi, J. N. (2011). The Effects Of Human Resource Development On Operational And Financial Performance Of Manufacturing Companies: A Large-Scale, Longitudinal Analysis. HRD Practices, Employee Outcome and Organizational Performance.

Warisno, W. (2009). Faktor-Faktor yang Mempengaruhi Kinerja Satuan Kerja Perangkat Daerah (SKPD) di Lingkungan Pemerintah Provinsi Jambi. Program Pascasarjana Universitas Sumatera Utara Medan.

Werther, W. B., \& Davis, K. (1996). Human Resources and Personnel Management (5th ed.). New York: Mc Graw Hill Companies Inc. 